\title{
The Effect of Topography on Long-Term Spontaneous Development of Soil and Woody Cover on Graded and Untreated Overburden
}

\author{
Fabio Vicentini ${ }^{1}$, Markéta Hendrychova ${ }^{2}$, Karel Tajovský ${ }^{3}{ }^{\mathbb{D}}$, Václav Pižl ${ }^{3}$ and Jan Frouz ${ }^{1,3,4, * \mathbb{B}}$ \\ 1 Institute for Environmental Sciences, Faculty of Science, Charles University, Benátská 2, 12800 Prague, \\ Czech Republic; fabio.vicentini@natur.cuni.cz \\ 2 Department of Ecology, Faculty of Environmental Science, Czech University of Life Sciences Prague, \\ Kamýcká 129, 16000 Prague 6-Suchdol, Czech Republic; hendrychovam@fzp.czu.cz \\ 3 Biology Centre of the Czech Academy of Sciences, Institute of Soil Biology, Na Sádkách 7, \\ 37005 Česke Budějovice, Czech Republic; tajov@upb.cas.cz (K.T.); pizl@upb.cas.cz (V.P.) \\ 4 Environmental Center, Charles University, José Martího 2, 16000 Prague, Czech Republic \\ * Correspondence: frouz@natur.cuni.cz
}

Received: 1 April 2020; Accepted: 20 May 2020; Published: 25 May 2020

\begin{abstract}
We studied the development of soil and soil fauna, as well as selected vegetation parameters important for litter input into soil, in two chronosequences of postmining sites after opencast lignite mining near the town of Most (Czechia). Both chronosequences did not have tree planting. On the first chronosequence, no leveling or any other measures had taken place after heaping, and the site kept the wavelike appearance created by the dumping process. The second chronosequence was formed by sites levelled by earthmoving machinery and in which shallow topsoil layers were spread. Both chronosequences were about 30 years old, and consisted of 8 and 11 sites for wavelike and levelled sites, respectively. In addition, samples were taken from a birch site outside of the heaps. Results showed differences in the development of tree and herb layers in both chronosequences. In the levelled sites, herb and tree cover increased after levelling, and woody cover developed much slower. In ungraded sites, woody cover developed faster, and the herb layer slower. Soil chemistry showed a similar pattern in both sites over time, characterized by a decrease in $\mathrm{pH}$ and sodium ion content. Soil macrofauna in levelled sites showed random oscillations, while it gradually increased with time in wavelike sites. The study suggested that site levelling alters long-term ecosystem development in postmining sites. Wavelike sites tend to develop towards pioneer forests, while leveled sites tend to be covered by grass and herb vegetation.
\end{abstract}

Keywords: biodiversity conservation; restoration ecology; habitat heterogeneity; vegetation dynamics; fauna colonization

\section{Introduction}

Postmining sites offer a unique opportunity to investigate environmental processes due to the synchronic presence of different stages of soil succession in a restricted area. Procedures to preserve and implement benefits to the ecosystem that postmining sites offer are a topic open for further investigation and discussion [1-4].

The levelling or bulldozing of heaps of overburden left behind after mineral extraction is a common practice that takes place at the start of the restoration of postmining sites [5-7]. As a result of this intervention, microtopographic heterogeneity, represented by heaps that form waves on the land, is typically suppressed, reducing the landscape to a levelled area that reduces the variability of environments available for plants and fauna. Furthermore, bulldozing is often followed 
by fertilizer application that increases site ruderalization and results in a decrease of their conservation potential $[3,4,6,8]$.

Previous studies showed that bulldozing in the western mining areas of the Czech Republic suppressed tree growth and promoted grasses, especially the grass Calamagrostis epigejos, which is known to outcompete herbs and other plants and to reduce the diversity of plant communities $[1,9]$. Similar results were observed in other studies in different geographic areas [10,11], causing an impoverishment of the land. These are opposed to outcomes obtained by spontaneous succession where the lack of bulldozing and fertilization was related positively to a restoration of postmining ecosystems that led to them harboring substantial diversity and habitats for rare and endangered species [7]. Such studies showed how overburden, which experienced several decades of spontaneous succession, achieved a quality comparable with technically reclaimed sites with respect to providing ecosystem services such as water retention or the production of woody biomass [12,13].

In this study, we used a chronosequence approach to evaluate ecosystem changes during succession. A chronosequence approach is commonly used to study long-term ecosystem processes, and it is based on a comparison of sites of various ages following a similar trajectory of development. Chronosequence studies of postmining sites are very common in botany, and vast numbers of studies exist about changes of plant communities during succession in these sites, including the area that we studied [14-16]. However, other parts of the ecosystem, such as soil development or soil fauna, are studied less often. Here, we used a chronosequence approach to study changes in soil chemistry, soil fauna, and a major component of vegetation responsible for input of organic matter to the soil during ecosystem development. This was done on two parallel chronosequences with different site topographies.

Heterogeneity in the environment is considered a key factor in biodiversity [17-19], as it offers a higher number of ecological niches from which a more variegated community of organisms is capable of benefitting $[17,20,21]$. Various studies focused on arthropods and their primary succession in postindustrial landscapes $[4,7,8,22,23]$. The effects of habitat heterogeneity on the biodiversity of postmining sites are usually studied on a large scale $[17,18,22,24,25]$, whereas the microtopographic scale (i.e., the influence of environmental heterogeneity measured over a few meters) is rarely studied [5,26-28].

Previous studies showed that grading the surface of the heap promotes plant communities dominated by grasses, which prefer a flat and compacted surface. On the other hand, keeping the wavelike topography of the heap created during the heaping process results in a heterogeneous habitat and a loose substrate, which results in the establishment of woody vegetation and affects the composition of soil invertebrates $[5,29]$. However, these studies were conducted in a limited geographical area, and focused only on the initial stages of succession. Here we used a chronosequence of graded and nongraded wavelike postmining sites near Most to test the validity of conclusions from studies on the effect of grading on woody vegetation in other areas and during long-term ecosystem development. In particular, we tested three hypotheses: (H1) grading supports the development of dense grass cover that slows down the establishment of woody vegetation, while on ungraded substrate, woody vegetation establishes much faster and develops toward forest over time; (H2) this results in the fast development of soil fauna in graded plots that stagnate or even decrease, while in ungraded sites, development is slower but gradually increases over time.

\section{Materials and Methods}

\subsection{Study Sites}

The study was carried out in two chronosequences of postmining sites after opencast lignite mining near the town of Most (northwest part of the Czech Republic, central Europe). Mean annual temperature is $9{ }^{\circ} \mathrm{C}$ and annual precipitation $837 \mathrm{~mm}$. Both chronosequences were created by the dumping of overburden consisting of tertiary clays. No trees had been planted in either chronosequence. The first chronosequence consisted of sites where no levelling or any other technical measures had 
taken place after heaping, and sites kept their wavelike appearance created by the dumping process. The second chronosequence was formed by sites that were levelled by earthmoving machinery, and, in most sites, a shallow topsoil layer was spread. After initial establishment, both types of sites developed spontaneously. Both chronosequences were about 30 years old and consisted of 8-11 sites. In addition, a birch site outside of the heaps was sampled. This site was similar in age to the oldest chronosequence, but had soil that was not affected by mining. It was used to investigate how soil properties in chronosequence sites compared to mature soil. Plot age (time since heaping) was determined on the basis of historical data supplied by the coal-mining company. As a result of the heaping process, parallel rows of depressions and elevations were formed in each site. The distance between rows was 4-8 $\mathrm{m}$ and elevation about $1 \mathrm{~m}$. In all sites selected for the study, no tree planting or subsequent manipulation, in addition to what has been described above, was performed. The sites developed spontaneously from heaping and initial treatment with levelling as described above. For pictures of the sites, see Figure S1. Coordinates of the sites are given in Table S1.

\subsection{Sampling and Analyses}

A vegetation survey was conducted in the center of each site in a $5 \times 5 \mathrm{~m}$ quadrant. In this quadrant, the coverage of herbs, grasses, and woody vegetation, expressed as percentages, was visually estimated, as well as the cover of woody species. To measure the litter input from woody vegetation, the litter was collected using litter collectors. The litter collectors consisted of sacks made from nylon mesh with $0.5 \mathrm{~mm}$ mesh size fixed on a wooden $0.5 \times 0.5 \mathrm{~m}$ frame about $0.5 \mathrm{~m}$ above the soil surface. Two collectors (one in the depression and one in the elevation) were used on each plot close to the center of the sampling site. If woody vegetation was present, the collectors were located equidistant between neighboring shrubs or trees. The litter collectors were deployed from August until all the leaves had fallen by the end of November. The litter was collected and transported to the laboratory. The litter and above-ground biomass samples were dried at $35^{\circ} \mathrm{C}$ for 7 days and weighed, with weights expressed per $\mathrm{m}^{2}$.

For chemical analyses, composite soil samples consisting of 5 individual subsamples (100 $\mathrm{g}$ of topsoil up to a depth of $5 \mathrm{~cm}$ below the litter layer) were taken in each plot in March 2004 from levelled and wavy sites (Figure 1). In the wavy sites, composite samples were obtained by combining a subsample from the depressions with one from the elevations. Samples were transported to the laboratory, homogenized, sieved through a $2 \mathrm{~mm}$ sieve, and dried. $\mathrm{pH}$ was measured in suspensions consisting of a 1:5 sample-to-liquid ratio. The content of available $\mathrm{Na}, \mathrm{K}$, and $\mathrm{Ca}$ was determined using ion-sensitive electrodes in an extract with a $1 \%$ citric acid solution (sample:liquid ratio of 1:5; shaken for $1 \mathrm{~h}$ ). Total $\mathrm{P}$ content was determined after mineralization of the sample in perchloric acid, and water-soluble $\mathrm{P}$ was determined in a water solution (sample:liquid ratio of 1:5; shaken for $1 \mathrm{~h}$ ).

Soil fauna was sampled in March 2004. To study soil fauna, two composite samples were taken (one from the depression and the one from the elevation) in each plot, each consisting of five particular samples (area of each $10 \mathrm{~cm}$ in diameter, depth $5 \mathrm{~cm}$ ). Fauna was extracted with a Kempson apparatus. Soil macrofauna (invertebrates bigger that $2 \mathrm{~mm}$ ) was identified into orders. Lumbricidae, Diplopoda, Isopoda, and Chilopoda were identified to the species level. 


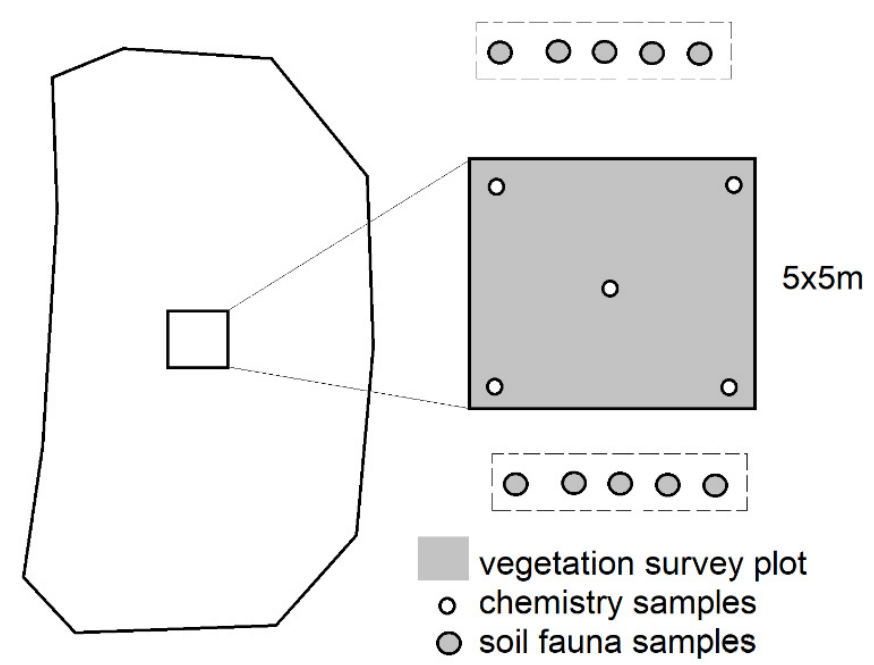

Figure 1. Sampling design applied on individual plots.

\subsection{Statistical Evaluation}

Individual parameters were fitted by a linear Statistica 10.0 program package to analyze the main trends of temporal changes. Only significant relationships were considered. To test the differences in individual parameters between particular time periods, general linear models (GLM) with an LSD post hoc test were computed using the Statistica 10.0 program package, with plot age as a continual predictor, and heterogeneity, i.e., flat vs. wavy, as a categorical predictor. Principal-component analysis (PCA) of woody plant and soil invertebrate communities in relation to environmental variables was computed using CANOCO 4.5. The positions of individual sites on the first two ordination axes were tested using Student's $t$-test.

\section{Results}

The development of vegetation cover with site age was different between graded sites and sites where the original wavelike surface was maintained. In flat graded areas, there was significantly greater herb cover (Figure 2a). Moreover, percentage herb cover in these sites was already high during the initial stages and slightly decreased with site age. Most of the herb layer in all sites was formed by the Calamagrostis epigejos grass. In contrast, no herb cover was present during initial stages in wavy sites and increased with time. Consequently, the difference in herb cover between flat and wavy sites decreased in the older, later stages of succession. Woody cover (Figure $2 b$ ) was significantly higher in wavy areas than that in levelled sites in all stages of succession. In flat areas, woody cover increased slowly in the last stages, whereas in wavy areas, the increment started during the younger phases and, in the 20-year-old site, it reached $60 \%-80 \%$ cover. The most abundant woody vegetation in flat areas was elder (Sambucus nigra) and roses (Rosa canina). Woody vegetation in wavy sites was dominated by birch (Betula pendula), with Salix caprea and Populus tremula being common (Table S2). PCA showed distinct differences in the composition of dominant woody species between flat, levelled, and unlevelled sites that kept a wavy appearance (Figure 3). This was supported by a significant difference in the position of wavy and flat sites along the first ordination axis ( $p<0.01, t$-test). In a similar manner as woody and herb covers behave, woody and herb litters also do, which differ in development over time with regard to wavy and flat sites (Table S1). 


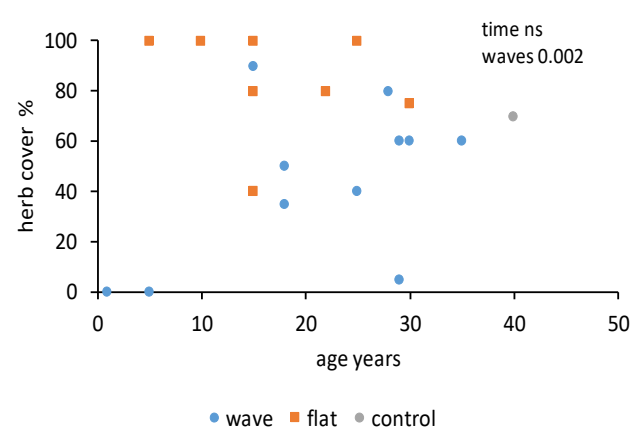

(a)

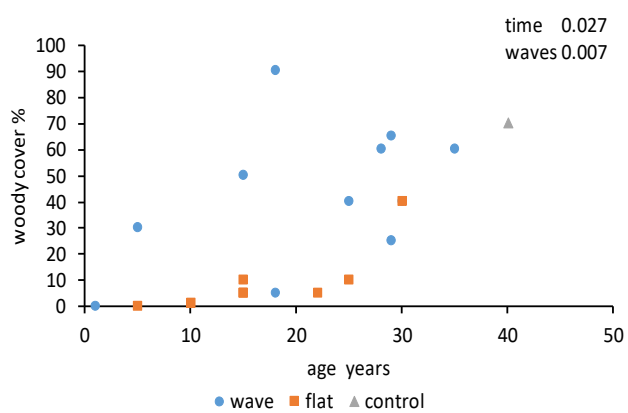

(b)

Figure 2. (a) Herb and (b) woody cover in postmining sites of various ages that were either levelled (flat) or not (wave). Control was forest unaffected by mining; $p$ values shown for effect of plot age (time) and presence of wavy surfaces (waves).

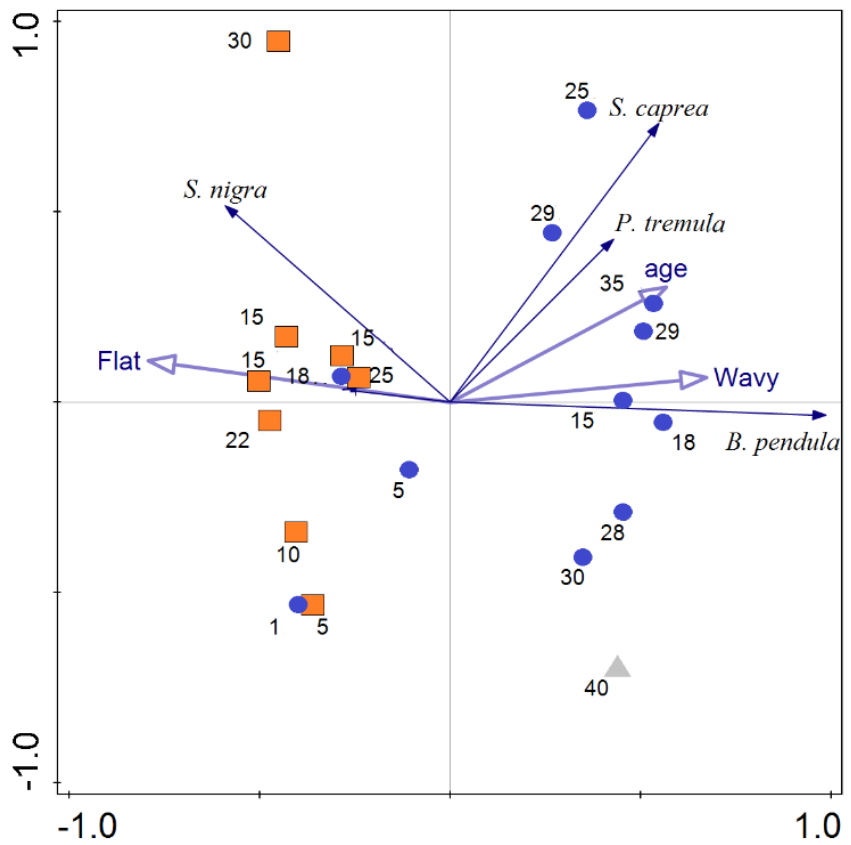

Figure 3. Principal-component analysis (PCA) of dominant tree and shrub composition in postmining sites of various ages that were either levelled (orange squares) or not (blue circles), and a forest unaffected by mining (grey triangle).

Soil-chemistry conditions were similar in both types of overburden management (Figure 4). $\mathrm{pH}$ in both graded and undegraded areas decreased slowly with site age, generally being more basic in the younger sites and becoming more acidic in the older sites (Figure 4a). Available phosphorus was not affected by site age or levelling (Figure 4 b). Sodium concentration (Figure $4 \mathrm{c}$ ) was significantly decreased by site age, and there was no significant effect of overburden grading, although it remained in higher concentrations in wave areas than in flat areas over time. 


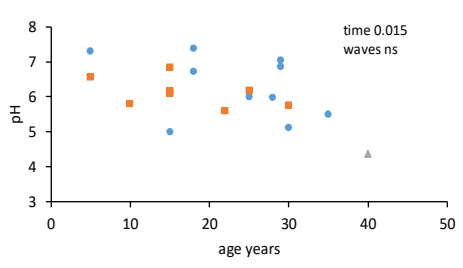

- wave 1 flat $\Delta$ control

(a)

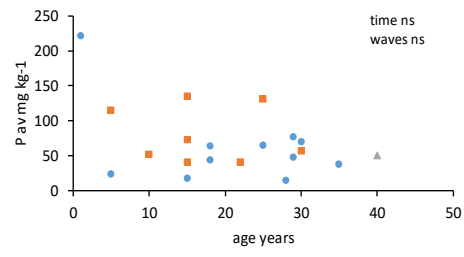

- wave $=$ flat $\Delta$ control

(b)

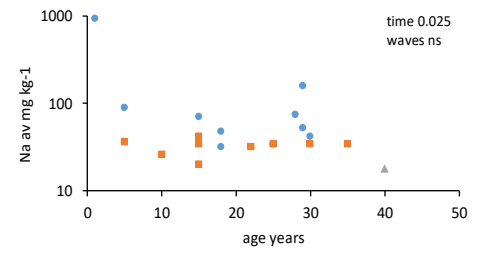

- wave 1 flat $\Delta$ control

(c)

Figure 4. Chemical factors: (a) $\mathrm{pH},(\mathbf{b})$ available phosphorus, and (c) sodium in postmining sites of various ages that were either levelled (flat) or not (wave). Control was a forest unaffected by mining; $p$ values shown for effect of plot age (time) and presence of wavy surfaces (waves).

None of the soil fauna groups was significantly affected by either age or surface levelling (Figure 5). In most groups, populations in wavy ungraded sites showed a tendency to increase over time, while in graded sites, maximal abundance was found in sites of early or middle age. Different parameters between flat and wavy areas were identified by PCA (Figure 6) when age and type of substrate were considered together. There was a clear distinction between levelled and wavy sites, but no clear effect over time, as supported by a significant difference between the position of flat and wavy sites along the second ordination axis (Figure 6; $p<0.05, t$-test). Earthworms (Lumbricidae) and terrestrial isopods (Oniscidea) tended to be more abundant in wavy sites, while millipedes (Diplopoda), fly larvae (Diptera), and centipedes (Chilopoda) were found in greater densities in levelled sites. Considering the species composition of dominant groups (Table S3), four species of earthworm were found. Endogenic Aporectodea calliginosa dominated among earthworms. Two eurytopic species of isopods, Trachelipus rathkii and Armadillidium vulgare, were found. Ten species of millipedes dominated by Polyzonium germanicum and Megaphyllum unilineatum, and eight species of centipedes, dominated by Lithobius microps and Schendyla nemorensis, were found.

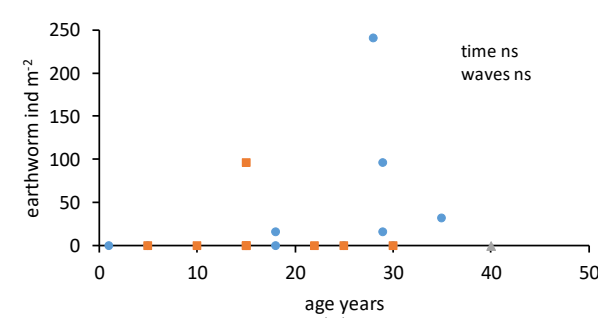

(a)

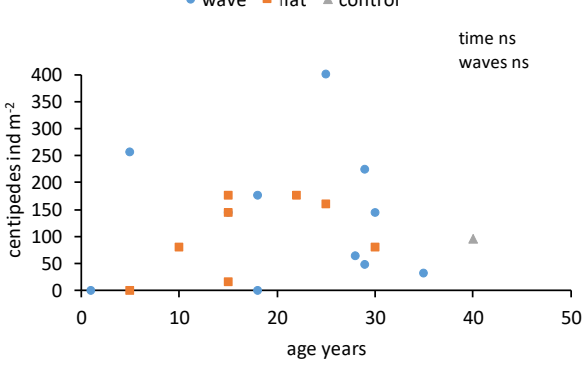

- wave - flat $\Delta$ control

(c)

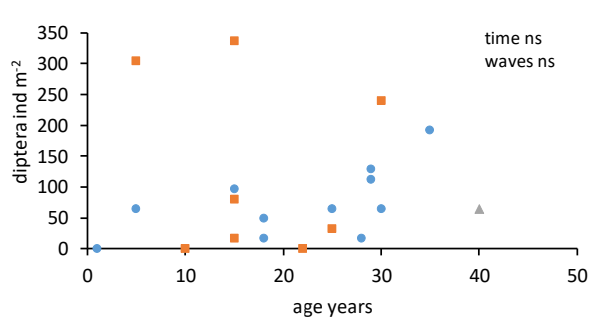

(b)

$\begin{array}{ll}\text { - wave } 1 \text { flat } & \begin{array}{l}\text { timens } \\ \text { control }\end{array} \\ \text { waves ns }\end{array}$

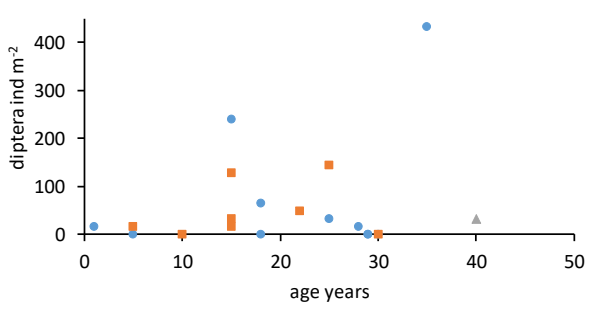

- wave $=$ flat $\Delta$ control

(d)

Figure 5. (a) Earthworms, (b) dipterans, (c) centipedes, and (d) millipedes in postmining sites of various ages which were either levelled (flat) or not (wave). Control was a forest unaffected by mining; $p$ values shown for effect of plot age (time) and presence of wavy surfaces (waves). 


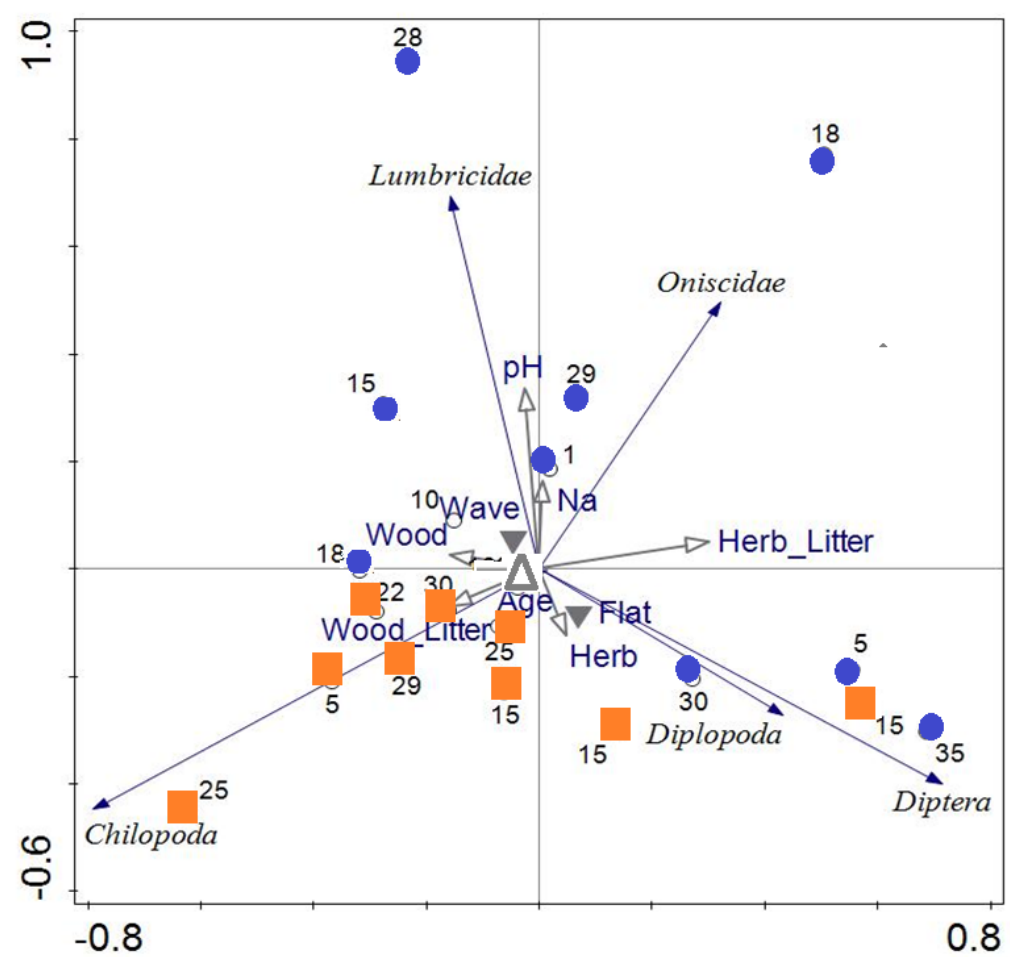

Figure 6. PCA of fauna composition in postmining sites of various ages that were either levelled (orange squares) or not (blue circles). Control is a forest unaffected by mining (grey triangle).

\section{Discussion}

In agreement with our hypothesis, we observed that grass vegetation dominated in levelled sites and remained the principal component as the site aged. In contrast, grass cover receded with age in wavy sites, leaving wood cover to take over in the older stages. Frouz et al. [5] mentioned that levelling caused substrate compaction that could suppress tree development and lead to the increased presence of grass species with major competitive capacity, such as Calamagrostis epigejos. Adverse effects of overburden compaction on tree establishment were reported in studies from the eastern United States $[10,11,30,31]$. Levelling of the site was followed by a supply of nutrients derived from covering the soil surface with a layer of fertile topsoil or applying various fertilizers. This practice may even more support grass in levelled site [8,10]. Moreover, levelling is known to reduce the heterogeneity of various environmental conditions and homogenize habitats $[5,15]$ that can reduce the availability of space needed for woody-vegetation establishment. Most previous studies on the effects of levelling compared sites of one age or over a relatively short period of time, whereas our study showed that initial site levelling may affect future ecosystem development for a long period of time, such as several decades or over a century.

In contrast to the apparent effect on the proportion of grass and woody vegetation, the mean values of soil chemistry did not seem to be much affected by levelling, although some measurements showed apparent changes with site age. The absence of differences in soil chemistry contrasted with findings in several previous studies that showed pronounced effects of surface heterogeneity on soil chemistry $[27,32,33]$. However, previous studies compared individual microhabitats within wavelike sites such as elevation and depression, which showed remarkable differences. In our study, we sampled all these microhabitats and pooled them in a composite sample so that the data represented mean values of the plot. These mean values did not differ between levelled and wavelike sites. This conclusion agrees with studies conducted in other postmining sites $[9,34]$ that showed that, when mean values from individual sites were considered, the overall pattern was similar in levelled and wavelike sites. Concerning the effects on soil chemistry over time, the most pronounced change was a decrease in $\mathrm{pH}$ and in sodium content. This agrees with observations made of other sites where Miocene clays formed 
the dominant part of the overburden $[9,33,34]$; this is due to, most likely, the gradual leaching of basic cations from the substrate, which was highly alkaline at the beginning.

Fauna showed remarkable differences between levelled and wavy areas. Despite higher heterogeneity in wavy areas, the community of investigated invertebrates was richer in flat areas than that in wavy areas. This is in contrast to some other studies, showing that wavy surface structures offer highly heterogeneous biotic and abiotic habitat conditions for their soil fauna and vegetation [3], and that levelling may reduce this diversity [35], causing a lack of suitable niches for organisms. This supports the conclusion by Moradi et al. [29] that, to maximize the diversity and nature-protection value of postmining sites, we need to maintain a mosaic of levelled and nonlevelled wavelike sites. The species composition of the dominant groups of soil fauna was similar to that of other postmining sites in Europe [20].

\section{Conclusions}

Surface levelling supports the dominance of expansive grasses, and reduces woody vegetation, which is promoted on ungraded surfaces. As a consequence, macrofauna colonizes graded sites sooner but does not show much development over time, while it increases over time in wavy sites.

Supplementary Materials: The following are available online at http://www.mdpi.com/1999-4907/11/5/602/s1, Figure S1 examples freshly dumped post mining site (a), and older site with wave like surface (b) and flat site with leveled surface (c). Table S1 Location of studied post mining sites and basic vegetation and chemistry data. Table S2 Percentage of cover of dominant woody species, in individual sites, $\mathrm{C}$ means control forest outside mining site. Table S3 Presence and absence of individual species of Diplopoda, Isopoda, Chilopoda and Lumbricidae, C means control forest outside post mining sites.

Author Contributions: Conceptualization, J.F.; methodology, J.F., K.T., V.P., M.H.; investigation, J.F., K.T., V.P., M.H.; F.V.; writing — original draft preparation F.V.; writing — review and editing, J.F.; visualization, F.V.; supervision, J.F; funding acquisition, J.F. All authors have read and agreed to the published version of the manuscript.

Funding: This research was funded by Ministerstvo Školství, Mládeže a Tělovýchovy: 8120001.

Acknowledgments: The study was funded by the PROGRES Environmental research program provided by Charles University and by the Ministry of Education, Youth, and Sports of the Czech Republic (MEYS) (project, EF16_013/0001782). We thank Lara Cameron for the language correction and proofreading the MS.

Conflicts of Interest: The authors declare no conflict of interest.

\section{References}

1. Mudrák, O.; Frouz, J.; Velichová, V. Understory vegetation in reclaimed and unreclaimed post-mining forest stands. Ecol. Eng. 2010, 36, 783-790. [CrossRef]

2. Tropek, R.; Cerna, I.; Straka, J.; Čížek, O.; Konvička, M. Is coal combustion the last chance for vanishing insects of inland drift sand dunes in Europe? Biol. Conserv. 2013, 162, 60-64. [CrossRef]

3. Tropek, R.; Hejda, M.; Kadlec, T.; Spitzer, L. Local and landscape factors affecting communities of plants and diurnal Lepidoptera in black coal spoil heaps: Implications for restoration management. Ecol. Eng. 2013, 57, 252-260. [CrossRef]

4. Tropek, R.; Kadlec, T.; Hejda, M.; Kocarek, P.; Skuhrovec, J.; Malenovsky, I.; Vodka, S.; Spitzer, L.; Banar, P.; Konvička, M. Technical reclamations are wasting the conservation potential of post-mining sites. A case study of black coal spoil dumps. Ecol. Eng. 2012, 43, 13-18. [CrossRef]

5. Frouz, J.; Mudrák, O.; Reitschmiedová, E.; Walmsley, A.; Vachová, P.; Šimáčková, H.; Albrechtová, J.; Moradi, J.; Kučera, J. Rough wave-like heaped overburden promotes establishment of woody vegetation while leveling promotes grasses during unassisted post mining site development. J. Environ. Manag. 2018, 205, 50-58. [CrossRef] [PubMed]

6. Prach, K.; Hobbs, R.J. Spontaneous succession versus technical reclamation in the restoration of disturbed sites. Restor. Ecol. 2008, 16, 363-366. [CrossRef]

7. Tropek, R.; Kadlec, T.; Karesova, P.; Spitzer, L.; Kocarek, P.; Malenovsky, I.; Banar, P.; Tuf, I.H.; Hejda, M.; Konvička, M. Spontaneous succession in limestone quarries as an effective restoration tool for endangered arthropods and plants. J. Appl. Ecol. 2010, 47, 139-147. [CrossRef] 
8. Tropek, R.; Konvička, M. Should restoration damage rare biotopes? Biol. Conserv. 2011, 144, 1299. [CrossRef]

9. Shu, W.S.; Ye, Z.H.; Zhang, Z.Q.; Lan, C.Y.; Wong, M.H. Natural Colonization of Plants on Five Lead/Zinc Mine Tailings in Southern China. Restor. Ecol. 2005, 13, 49-60. [CrossRef]

10. Ashby, W.C. Reclamation with trees pre- and post-SMCRA in Southern Illinois. Int. J. Surf. Mining Reclam. Environ. 1998, 12, 117-121. [CrossRef]

11. Zipper, C.E.; Burger, J.A.; Skousen, J.G.; Angel, P.N.; Barton, C.D.; Davis, V.; Franklin, J.A. Restoring forests and associated ecosystem services on Appalachian coal surface mines. Environ. Manag. 2011, 47, 751-765. [CrossRef] [PubMed]

12. Cejpek, J.; Kuráž, V.; Frouz, J. Hydrological properties of soils in reclaimed and unreclaimed sites after brown-coal mining. Polish J. Environ. Stud. 2013, 22, 645-652.

13. Kuráž, V.; Frouz, J.; Kuráž, M.; Mako, A.; Shustr, V.; Cejpek, J.; Romanov, O.V.; Abakumov, E.V. Changes in some physical properties of soils in the chronosequence of self-overgrown dumps of the Sokolov quarry-dump complex, Czechia. Eurasian Soil Sci. 2012, 45, 266-272. [CrossRef]

14. Baasch, A.; Kirmer, A.; Tischew, S. Nine years of vegetation development in a postmining site: Effects of spontaneous and assisted site recovery. J. Appl. Ecol. 2012, 49, 251-260. [CrossRef]

15. Boscutti, F.; Vianello, A.; Bozzato, F.; Casolo, V. Vegetation structure, species life span, and exotic status elucidate plant succession in a limestone quarry reclamation. Restor. Ecol. 2017, 25, 595-604. [CrossRef]

16. Prach, K.; Řehounková, K.; Lencová, K.; Jírová, A.; Konvalinková, P.; Mudrák, O.; Študent, V.; Vaněček, Z.; Tichý, L.; Petřík, P.; et al. Vegetation succession in restoration of disturbed sites in Central Europe: The direction of succession and species richness across 19 seres. Appl. Veg. Sci. 2014, 17, 193-200. [CrossRef]

17. Stein, A.; Gerstner, K.; Kreft, H. Environmental heterogeneity as a universal driver of species richness across taxa, biomes and spatial scales. Ecol. Lett. 2014, 17, 866-880. [CrossRef]

18. Tews, J.; Brose, U.; Grimm, V.; Tielbörger, K.; Wichmann, M.C.; Schwager, M.; Jeltsch, F. Animal species diversity driven by habitat heterogeneity/diversity: The importance of keystone structures. J. Biogeogr. 2004, 31, 79-92. [CrossRef]

19. Yang, Z.; Liu, X.; Zhou, M.; Ai, D.; Wang, G.; Wang, Y.; Chu, C.; Lundholm, J.T. The effect of environmental heterogeneity on species richness depends on community position along the environmental gradient. Sci. Rep. 2015, 5, 15723. [CrossRef]

20. Frouz, J.; Pižl, V.; Tajovský, K.; Starý, J.; Holec, M.; Materna, J. Soil macro- and mesofauna succession in post-mining sites and other disturbed areas. In Soil Biota and Ecosystem Development in Post Mining Sites; Frouz, J., Ed.; CRC: Boca Rato, FL, USA, 2014.

21. Williams, B.M.; Houseman, G.R. Experimental evidence that soil heterogeneity enhances plant diversity during community assembly. J. Plant Ecol. 2014, 7, 461-469. [CrossRef]

22. Hendrychová, M.; Šálek, M.; Tajovský, K.; Řehoř, M. Soil properties and species richness of invertebrates on afforested sites after brown coal mining. Restor. Ecol. 2012, 20, 561-567. [CrossRef]

23. Heneberg, P.; Bogusch, P.; Řehounek, J. Sandpits provide critical refuge for bees and wasps (Hymenoptera: Apocrita). J. Insect Conserv. 2013, 17, 473-490. [CrossRef]

24. Doležalová, J.; Vojar, J.; Smolová, D.; Solský, M.; Kopecký, O. Technical reclamation and spontaneous succession produce different water habitats: A case study from Czech post-mining sites. Ecol. Eng. 2012, 43, 5-12. [CrossRef]

25. Tichánek, F.; Tropek, R. Conservation value of post-mining headwaters: Drainage channels at a lignite spoil heap harbour threatened stream dragonflies. J. Insect Conserv. 2015, 19, 975-985. [CrossRef]

26. Deák, B.; Valkó, O.; Török, P.; Kelemen, A.; Miglécz, T.; Szabó, S.; Szabó, G.; Tóthmérész, B. Micro-topographic heterogeneity increases plant diversity in old stages of restored grasslands. Basic Appl. Ecol. 2015, 16, 291-299. [CrossRef]

27. Frouz, J.; Kalčík, J.; Velichová, V. Factors causing spatial heterogeneity in soil properties, plant cover, and soil fauna in a non-reclaimed post-mining site. Ecol. Eng. 2011, 37, 1910-1913. [CrossRef]

28. Kappes, H.; Clausius, A.; Topp, W. Historical small-scale surface structures as a model for post-mining land reclamation. Restor. Ecol. 2012, 20, 322-330. [CrossRef]

29. Moradi, J.; Potocký, P.; Kočárek, P.; Bartuška, M.; Tajovský, K.; Tichánek, F.; Frouz, J.; Tropek, R. Influence of surface flattening on biodiversity of terrestrial arthropods during early stages of brown coal spoil heap restoration. J. Environ. Manag. 2018, 220,1-7. [CrossRef] 
30. Franklin, J.A.; Zipper, C.E.; Burger, J.A.; Skousen, J.G.; Jacobs, D.F. Influence of herbaceous ground cover on forest restoration of eastern US coal surface mines. New For. 2012, 43, 905-924. [CrossRef]

31. Zeleznik, J.; Skousen, J. Survival of three tree species on old reclaimed surface mines in Ohio. J. Environ. Qual. 1996, 25, 1429-1435. [CrossRef]

32. Frouz, J.; Nováková, A. Development of soil microbial properties in topsoil layer during spontaneous succession in heaps after brown coal mining in relation to humus microstructure development. Geoderma 2005, 129, 54-64. [CrossRef]

33. Frouz, J.; Prach, K.; Pižl, V.; Háněl, L.; Starý, J.; Tajovský, K.; Materna, J.; Balík, V.; Kalčík, J.; Řehounková, K. Interactions between soil development, vegetation and soil fauna during spontaneous succession in post mining sites. Eur. J. Soil Biol. 2008, 44, 109-121. [CrossRef]

34. Frouz, J.; Kalčík, J. Accumulation of soil organic carbon in relation to other soil characteristic during spontaneous succession in non reclaimed colliery spoil heaps after brown coal mining near Sokolov (the Czech Republic). Ekologia 2006, 25, 388-397.

35. Benes, J.; Kepka, P.; Konvička, M. Limestone quarries as refuges for European xerophilous butterflies. Conserv. Biol. 2003, 17, 1058-1069. [CrossRef]

(C) 2020 by the authors. Licensee MDPI, Basel, Switzerland. This article is an open access article distributed under the terms and conditions of the Creative Commons Attribution (CC BY) license (http://creativecommons.org/licenses/by/4.0/). 